\title{
SÍLVIO ROMERO VS. MACHADO DE ASSIS: \\ CRÍTICA LITERÁRIA VS. LITERATURA CRÍTICA
}

\section{SILVIO ROMERO VS. MACHADO DE ASSIS: LITERARY CRITICISM VS. CRITIC LITERATURE}

\author{
Maria Elizabeth Chaves de Mello*
}

RESUMO: Durante o século XIX, a luta pela identidade nacional, no Brasil, é feita com a ajuda de idéias e ideologias européias, oriundas principalmente da França. Diante de um público leitor muito escasso, os críticos literários, pretendendo investigar o que deveria ser o escritor nacional, dedicam-se a polêmicas sobre idéias européias, sem reflexão sobre o que viria a ser, realmente, o seu papel na sociedade. É o caso do mais importante deles, na época, Sílvio Romero, nos ataques que faz a Machado de Assis. Este último, que iniciara o ofício de escritor como crítico, percebendo o vazio dessas polêmicas, abandona esse gênero, dedicando-se a fazer literatura crítica.

PALAVRAS-CHAVE: crítica literária, Machado de Assis, Sílvio Romero, polêmica.

ABSTRACT: During the 19th century, Brazil struggled for its national identity was based on European ideas and ideologies, specially from France. In a country with very few readers, the literary critics, in an effort to define how should be the Brazilian writers, engaged in polemic debates about those European ideas, failing to take into consideration their role in that society. That would be the case of one of the most important literary critics of that time, Silvio Romero, who constantly attacked Machado de Assis' work. Assis, who was a critic before becoming a writer, understood how senseless those polemics were, decided to abandon literary criticism and dedicate himself to critic literature.

KEY WORDS: literary criticism, Machado de Assis, Sílvio Romero, polemics.

\footnotetext{
* Universidade Federal Fluminense, Niterói, Estado do Rio de Janeiro. Titulação: doutora. Professor assistente I. Pesquisadora PQ2 do CNPq. Email: bethcmello@gmail.com.
} 



\section{SÍLVIO ROMERO VS. MACHADO DE ASSIS: \\ CRÍTICA LITERÁRIA VS. LITERATURA CRÍTICA}

Tentar repensar lucidamente os textos dos autores da crítica literária brasileira do século XIX dá-nos, por vezes, a sensação vertiginosa de descermos um abismo em espiral, dando voltas em torno de um mesmo assunto, perplexos, sem conseguirmos chegar a uma conclusão. Isso decorre, em grande parte, da ausência de reflexão no pensamento crítico daquele momento no Brasil, que leva os nossos intelectuais a caírem em polêmicas sem fim, a propósito de tudo e de nada, para preencherem o vazio causado pela falta de leitores. Polêmicas emergem nas mínimas ocasiões, provocadas, muitas vezes, por conflitos que, na realidade, não têm a menor consistência. É o que acontece, por exemplo, no famoso caso Machado de Assis, em que, nos ataques ou na defesa do autor de Dom Casmurro, os seus contemporâneos deixaram vir claramente à tona a falta de reflexão do seu discurso, imbuído das idéias e ideologias que os guiavam, importadas da Europa, principalmente da França.

Gostaríamos de nos deter na leitura do bruxo do Cosme Velho feita por Sílvio Romero, o principal nome, daquele momento, no ofício de crítico literário no Brasil. Assim o fazemos, por considerarmos Romero bastante representativo da importação de idéias a que aludimos e porque, principalmente, é ele o 'papa' da crítica brasileira contemporânea a Machado de Assis. 
Podemos até mesmo datar o início dessa polêmica. Em 1879, Machado escreve o artigo A Nova Geração, em que critica o estilo de Sílvio Romero: Refiro-me ao estilo, condição indispensável do escritor, indispensável à própria ciência - o estilo que ilumina as páginas de Renan e de Spencer, e que Wallace admira como uma das qualidades de Darwin (MACHADO DE ASSIS, 1944, p. 195). Percebe-se, neste texto de Machado, a consciência da importância do papel primordial que o estilo representa na retórica da crítica, na arte de convencer o leitor. É pela força do discurso que historiadores, cientistas e homens de idéias em geral difundem o seu pensamento e tentam influenciar os seus leitores. Isto é ainda mais verdadeiro quando se trata do ficcional, pois aí, segundo o nosso autor, o estilo é condição indispensável. E ele não o reconhece em Sílvio Romero.

Ora, esta foi a fagulha que fez explodir a fúria de Sílvio Romero. Daí para a frente, o crítico atacará não só o romancista, mas também quem ousar defendê-lo. Além de inúmeros artigos em jornais, publicará um livro dedicado a criticar Machado de Assis. Este seria apenas mais um dos inúmeros duelos de retórica com que se divertia a intelectualidade brasileira, se não estivessem em questão idéias fundamentais naquele momento, herdeiras de teorias francesas: a questão do escritor nacional e, principalmente, englobando todas as outras, a problemática do racismo determinista.

Na verdade, o que logo à primeira vista nos parece evidente, é a tentativa, ao longo de todos os inúmeros textos que escreve Romero, de enquadrar Machado de Assis, começando por criticá-lo exatamente no ponto em que este último o atacara: chamando-o de mau poeta. Na poesia brasileira ele não foi um abridor de caminhos; bem ao contrário, foi um espírito submisso e continuador de trilhas conhecidas (ROMERO, 1936, prefácio). Daí Sílvio Romero conclui que Machado de Assis tem sido elogiado, mas não tem sido estudado.

Quem já o estudou à luz de seu meio social, da sua influência, de sua educação, de sua hereditariedade não só física como étnica, mostrando a formação, a orientação normal de seu talento? Quem já lhe 'assinou o posto' na história espiritual do país? (ROMERO, 1936, p. 18).

Em resumo, quem teria determinado o seu lugar? Diante desta pergunta, não resistimos à reflexão sobre a função do crítico, visto, tanto naquela época como hoje, como aquele que guia, marcando lugares, definindo, 
determinando funções. Só esta última questão já nos fornece muito material de reflexão, pois nos ajuda a pensar na problemática da crítica brasileira e da crítica literária e artística, em geral. Entretanto, se continuarmos a leitura do texto citado, veremos que ele contém uma definição bastante significativa do que seria 'estudar' para Sílvio Romero: ler à luz dos três fatores - meio, raça e momento -, responsáveis pela orientação normal de seu talento, ou seja, uma concepção absolutamente determinista do que seria a criação artística. Nesta linha, Romero adota o chamado 'critério nacionalístico' para julgar o nosso romancista pois, segundo ele,

(...) Machado de Assis não sai fora da lei comum, não pode sair, e ai dele, se saísse. Não teria valor. Ele é um dos nossos, um genuíno representante da subraça brasileira cruzada, por mais que pareça estranho tocar neste ponto (ROMERO, 1936, p. 28).

Observamos claramente, neste trecho, uma tentativa de 'enquadrar' Machado de Assis em uma 'brasilidade' que não lhe daria, entre outras coisas, o direito de escrever com humour e ironia. Mestiço, ele é um dos nossos, e só pode ser e escrever como todos os brasileiros. Por outro lado, percebemos a irritação de Romero diante do fato de que o romancista escapa às regras, não obedecendo a elas...

(...) Machado de Assis que (...) por dez anos seguidos, até 1870, (...) se manifestou tão plácido, tão brando, tão sossegado de índole, de aspirações e de estilo, não poderia de repente se transfigurar em grande filósofo, terrível manejador de 'humour', profundo pensador de espírito dissolvente e irritadiço, envolvendo a criação e a humanidade nas malhas de um pessimismo fulgarante (ROMERO, 1936, p. 48).

Ora, nas expressões não poderia e ai dele se saísse percebemos o autoritarismo determinista supracitado, segundo o qual um escritor brasileiro, mestiço, nascido nas camadas desfavorecidas e epiléptico não teria a menor possibilidade de escrever usando artifícios e técnicas, ou mesmo pensamentos mais elaborados, diferentes dos de sua condição. E ai dele se o fizesse! No caso machadiano, Sílvio Romero depara-se com um autor que se recusa a ser 'enquadrado', escapando a todas as regras da trindade taineana. Isto é o que mais desequilibra o nosso crítico, essa capacidade (ou ousadia) de 
Machado de Assis em desmentir as teorias elaboradas na Europa... É como se ele experimentasse uma perplexidade diante de uma transgressão ao não poderia tão tranqüilizador... Por que motivo pode o autor de Várias Histórias desmentir assim tão flagrantemente as leis do meio, da raça, e do momento? (ROMERO, 1936, p. 154).

Esta irritação e perplexidade acabam levando-o a afirmações maldosas, que são, inclusive, contraditórias com as próprias idéias de isenção, imparcialidade e objetividade do espírito positivista da época:

Ele gagueja no estilo, na palavra escrita, como fazem outros na palavra falada, disse-me uma vez não sei que desabusado num momento de expansão, sem reparar talvez que dava destarte uma verdadeira e admirável notação (ROMERO, 1936, p. 55).

Numa reviravolta do discurso, Sílvio Romero passa a condenar Machado de Assis exatamente no mesmo ponto em que fora por este último atacado: no estilo. Evidentemente, associando-o a questões biológicas: um estilo gago, como o era o seu autor. Mas, principalmente, um estilo sem força, sem paixão, resultante do tão decantado humour:

Mas o período não lhe sai possante e largo, porque seus pensamentos não são vastos, ou profundos, ou grandiosos; não lhe sai também rápido, intenso, incisivo, porque uma paixão forte não o anima ou move (ROMERO, 1936, p. 65).

Humour que não poderia ser brasileiro, pois não somos assim. E que, portanto, só pode ser macaqueação européia, imitação barata:

O humour de imitação é a caricatura mais desasada que se pode praticar em literatura.O humorista é porque é e porque não pode deixar de ser. Dickens, Carlyle, Swift, Sterne, Heine, foram humoristas fatalmente, necessariamente; não poderia ser por outra forma. A índole, a psicologia, a raça, o meio tinha de fazê-los como foram (ROMERO, 1936, p. 78).

Segundo Romero, os povos latinos são incapazes de humour. Por isto, a Machado é negado o direito de fazê-lo. Trata-se de mais uma regra transgredida, para grande indignação do crítico, cuja irritação chega ao seu auge quando ele aborda o famoso pessimismo machadiano. Considerando as idéias do crítico, os brasileiros também não podem ser pessimistas: 
Somos faladores, maldizentes, desrespeitadores das conveniências, assaz irrequietos, até onde nos deixa ir nossa ingênita apatia de meridionais, mas não somos pessimistas, nem nos agrada o terrível desencanto de tudo sob as formas desesperadoras dos nirvanistas a Budha ou a Schopenhauer (ROMERO, 1936, p. 105).

Ou seja, o pessimismo machadiano iria contra as leis estabelecidas para a sua condição de brasileiro e mestiço. Outra regra transgredida... Podemos dizer, portanto, que a análise que Sílvio Romero faz de Machado de Assis, cheia de expressões como não poderia, consiste em um jogo de interdição/transgressão, em que o bruxo do Cosme Velho se recusa a obedecer aos limites que lhe são impostos pelos herdeiros do determinismo. Sílvio Romero escreve todo um livro, assim como inúmeros ensaios e capítulos para atacá-lo. Mas nunca será rebatido por Machado de Assis, que se recusou a entrar na briga, revelando o que em um dos seus personagens, o Conselheiro Aires, é tão explícito: o tédio à controvérsia (MACHADO DE ASSIS, 1971 , v. 1, p. 965). Mais adiante retomaremos essa recusa do romancista em responder aos ataques do crítico, continuando a encontrá-lo na livraria Garnier, cumprimentá-lo e fingir não se dar conta do tumulto que ele criava em torno do seu nome.

Por enquanto, contentamo-nos em afirmar, a respeito de Romero, que ele estaria na difícil posição do intelectual brasileiro que, em uma sociedade dominada pelo cientificismo positivista, questiona a sua própria identidade, fruto, segundo essas idéias cientificistas e deterministas, de um povo mestiço, marcado pela inferioridade racial, na qual ele, Sílvio Romero, acredita piamente. Crença que resulta da mistura das teorias de Gobineau com as de Darwin, fornecendo-lhe material de importância vital na sua obra, e que o levará até a afirmar a inferioridade do negro e do índio: Todas as nações americanas em que o elemento europeu não predomina, como o México, Peru, Equador e Bolívia, são as menos progressivas do continente (ROMERO, 1980, v. IV, p. 1.136). E sugere que, no Brasil, será feita uma espécie de 'eugenia' natural: (...) o tipo branco irá tomando a preponderância até mostrar-se talvez depurado e belo como no Velho Mundo. Será quando já estiver melhor aclimatado no continente (ROMERO, 1902-1903, v. III, p. 243). 
Além de Gobineau, Darwin e Spencer, as idéias de Sílvio Romero são imbuídas, como vimos, da teoria de Taine, com os seus três fatores: raça, meio e momento. Romero se pergunta qual dos três teria contribuído em maior escala para a formação e diferenciação do caráter brasileiro, optando pela raça: A unidade nacional é garantida, a meu ver, pelos agentes morais e pela energia étnica (ROMERO, 1902-1903, v. III, p. 243). Assim, o crítico estabelece uma hierarquia em que a prioridade cabe à etnia e (...) o clima fica em segundo plano (...) já que ele também (...) foi um agente valentíssimo na formação das raças e das civilizações autóctones (ROMERO, 19021903, v. III, p. 243). Ou seja, Sílvio Romero acrescenta as idéias de Montesquieu às de Gobineau, Darwin e Taine, misturando a teoria da raça, meio e momento com a dos climas. Idéias européias, em sua maioria francesas, guiando, paradoxal e contraditoriamente, o crítico que luta pela libertação da importação do pensamento, para perplexidade do estudioso da crítica daquele momento...

Mas tem mais. Priorizando a raça, Romero afirma não perceber que diferenças tenha o meio produzido no caboclo, no negro e mesmo no português. O que noto a olhos nus é o mestiço (ROMERO, 1902-1903, v. IV, p. 413). Assim, o mestiço moveria a história brasileira, marcado pela questão étnica e pelo contato de várias culturas. A mestiçagem mais importante na formação da nossa cultura seria a afro-lusitana. O negro, espalhado pela África e América, é uma raça que oferece interessantíssimos problemas (ROMERO, 1978, p. 49). Podemos dizer que Sílvio Romero é um dos primeiros a destacar a importância do elemento africano, quando este era praticamente ignorado pela intelectualidade nacional. O que quer que notardes de diverso entre o brasileiro e o europeu, atribui-o em sua máxima parte ao preto (ROMERO, 1978, p. 3).

Para medir essa importância bastaria, segundo o nosso autor, que se levasse em conta uma mestiçagem muito mais interessante do que a étnica: a mestiçagem moral, conseqüência da educação dos filhos dos senhores de engenho, que cresciam brincando com os moleques da senzala e ouvindo das 'mães pretas' as histórias do Saci Pererê, do Zumbi, e muitos outros personagens e elementos da cultura africana. Isto fazia com que, mais tarde, se tornassem inteiramente diferentes dos seus pais portugueses: eram mestiços moralmente. Assim, o projeto de Sílvio Romero estaria voltado, cada vez mais, para a investigação sobre a contribuição cultural das raças. Partindo do ponto de vista arianista - segundo o qual os germanos, eslavos e saxões 
viveriam o progresso, enquanto que os latinos estariam em situação de decadência - ele chega à conclusão de que os portugueses formam um povo inferior, que trouxe para o Brasil os males crônicos das raças atrasadas. Daí a dependência cultural, a tendência à imitação do estrangeiro. Propõe, então, que se observe aqui no Brasil um outro elemento, além dos três fatores taineanos: a influência estrangeira. A literatura brasileira seria, portanto, o resultado da adaptação das idéias estrangeiras aos trópicos. O seu projeto consistiria, assim, na construção de uma cultura brasileira moderna, que integraria os modelos estrangeiros às temáticas locais.

Segundo Roberto Ventura, o racismo científico no Brasil funcionaria como (...) um instrumento conservador e autoritário de definição da identidade social da classe senhorial e dos grupos dirigentes, perante uma população considerada étnica e culturalmente inferior (VENTURA, 1991, p. 60). Seria, muito provavelmente, o resultado de um olhar 'de fora' lançado ao Brasil, que teria como conseqüência a imagem negativa da sociedade e da cultura local. Sílvio Romero, abraçando a idéia da nação como unidade cultural resultante do cruzamento das três raças, procura dar conta da sua gênese, inserindo-se na tradição do Iluminismo, que mistura a busca das raízes com a crença no progresso. A nação se constrói portanto no movimento ambíguo entre a identidade e a diferença, entre a reprodução da experiência européia e a sua relativa diferenciação nos trópicos (VENTURA, 1991, p. 60).

Assim, poderíamos afirmar que Romero se propõe a eliminar a contradição entre a realidade étnica brasileira, o racismo científico e o liberalismo progressista, através da opção pela mestiçagem, a que já nos referimos. Ou seja, pela extinção das raças não brancas através da fusão, da assimilação racial dos grupos inferiores. É nesta linha que Sílvio Romero propõe o 'branqueamento' como solução para reabilitar as raças ditas 'inferiores', o que seria uma solução para o dilema social sem contestar os fundamentos do racismo. Em rigor não há a perda daquelas duas raças; há a transformação delas (ROMERO, 1980, v. II, p. 179), com uma inevitável vitória do branco. Enfim, uma mistura dos princípios arianistas com as leis darwinistas, evolucionistas e sociais, numa busca de coerência onde esta é praticamente impossível. Na verdade, o que já podemos ir percebendo é que, apesar da aparência em contrário, há uma luta incessante do crítico pela lógica, pelo rigor científico, a ponto de tentar adaptar a realidade às suas idéias. O que, evidentemente, vai propiciar a descoberta de várias contradições na sua obra, por mais que ele busque exatamente o contrário. No caso, aqui, 
tentando descobrir um encadeamento lógico para o seu raciocínio, ele acaba misturando princípios diferentes. Mas será que poderíamos realmente chamá-lo de contraditório? Ou ele teria sido simplesmente uma vítima do acúmulo de idéias européias mal digeridas que aqui se instalam no século XIX? No caso Machado de Assis, Romero se irrita porque o escritor não se comporta como deveria se comportar (ou escrever) um mestiço, destruindo, portanto, toda a sua teoria...

Ora, como teria reagido o romancista diante de tão duros ataques? Já vimos que, aparentemente, ele não reagia, manifestando, através do seu personagem Conselheiro Aires, o famoso tédio à controvérsia. E chega a aconselhar a seus leitores a nunca se meterem nesse tipo de disputa: Não te envolvas com polêmicas de nenhum gênero, nem poéticas, nem literárias, nem quaisquer outras(...) o pugilato das idéias é muito pior do que o das ruas (apud PUJOL, 1934, p. 237).

No artigo A Nova Geração, Machado acrescenta, a respeito do mesmo tema:

Realmente, criticados que se deforçam de críticas literárias com impropérios dão logo idéia de uma imensa mediocridade - ou de uma fatuidade sem freio - ou de ambas as coisas; e para lances tais é que o talento, quando verdadeiro e modesto, deve reservar o silêncio do desdém (MACHADO DE ASSIS, 1944, p. 237).

Ora, por que esse tédio à controvérsia? Seria somente por questões de temperamento, como o querem muitos dos seus biógrafos? Ou seria por duvidar da eficácia de tais polêmicas, que tanto incendiavam a nossa república das letras? É curioso observar que só uma vez Machado aceitou discutir um assunto de crítica literária. E foi exatamente a respeito do naturalismo, a partir do romance O Primo Basílio, de Eça de Queiroz, no qual insiste em dizer que, embora muito admire o romancista português, recusa a escola naturalista a que ele pertenceu. E recusa-a principalmente porque ela leva a sério a ilusão do real: Porque a nova poética é isto e só chegará à perfeição no dia em que nos disser o número exato dos fios de que se compõe um lenço de cambraia ou um esfregão de cozinha (MACHADO DE ASSIS, 1944, p. 163).

Assim, não admitindo que a imitatio seja suficiente para a criação artística, buscando um outro conceito de objeto literário, Machado até aceita um início de polêmica no caso Eça de Queiroz. Chovem protestos em defesa 
do autor do Primo Basílio, aos quais Machado responde timidamente. Mas retrai-se a partir daí, fazendo cada vez menos crítica literária.

Retraimento interessante para o estudioso, porque Machado chegara a ser muito conhecido no exercício da crítica. A tal ponto, que, em 1868, José de Alencar lhe pede para promover o poeta Castro Alves, então recém-chegado ao Rio de Janeiro, que precisava de uma indicação para ser bem aceito nos meios literários:

O senhor foi o único dos nossos modernos escritores que se dedicou à cultura dessa difícil arte que se chama 'crítica'. Uma porção do talento que recebeu da natureza, em vez de aproveitá-lo em criações próprias, não duvidou aplicá-lo a formar o gosto e desenvolver a literatura pátria. Do senhor, pois, do primeiro crítico brasileiro, confio a brilhante vocação literária que se revelou com tanto vigor (apud PUJOL, 1934, p. 265).

Esta carta nos mostra, claramente, o prestígio que já alcançara Machado de Assis como crítico, com apenas dez anos de carreira, antes ainda de se lançar na aventura dos seus grandes romances e contos. Além disto, o texto de Alencar nos permite confirmar o que antes já afirmáramos a respeito do empenho da crítica em formar o gosto e desenvolver a literatura pátria para, assim, contribuir para o desenvolvimento da nação que se criava. E, no pedido do autor de Iracema ao futuro autor de Dom Casmurro, a evidência do papel a que se propunha a crítica, no sentido de promover nomes no cenário das letras.

Machado já havia sido consagrado na carreira de crítico, considerado o primeiro crítico brasileiro, como dissera Alencar. Entretanto, após a polêmica sobre Eça de Queiroz, provavelmente esgotado pela que envolvera de maneira tão dolorosa o seu nome, ele deixa praticamente de fazer crítica. Ou, na interpretação de Pujol: Retraiu-se a sua sensibilidade magoada; $e$, de então por diante, só raramente, em algum período fugitivo de crônica e num ou noutro esboço, atreveu-se a fazer crítica literária (PUJOL, 1934, p. 271).

Importa-nos, aqui, questionar a razão pela qual teria deixado o nosso escritor uma carreira tão bem iniciada, que já lhe valera do maior romancista da época o título de maior crítico brasileiro. Seria, realmente, por não ser capaz de enfrentar a polêmica em torno do seu nome? Por simples tédio à controvérsia, para responder com o silêncio do desdém? O que sabemos é que, pouco a pouco, principalmente a partir dessa polêmica que envolveu 
praticamente toda a intelectualidade brasileira do momento, Machado passa a fazer cada vez menos crítica literária. Tem verdadeiro horror às controvérsias que tanto preenchiam o vazio do pensamento na sua época. Carlos de Laet conta que, certa vez, para implicar com ele, disse ao romancista que ainda ia obrigá-lo a ter com ele uma polêmica. Machado teria retrucado, imediatamente: Não faça tal, respondeu-me a gaguejar ligeiramente, que os partidos não seriam iguais; isso para você seria uma festa, uma missa cantada na sua capela; e para mim uma aflição... (apud PUJOL, 1934, p. 271).

Seria mesmo por simples questões de temperamento que nosso escritor teria abandonado a crítica? Não estaríamos nós caindo no mesmo caso dos que o explicam pelos dados da sua vida, ou dos seus condicionamentos biológicos? Na verdade, se atentarmos para a data do artigo A Nova Geração, 1879, veremos que ele antecede de um ano as Memórias Póstumas de Brás Cubas, livro que se abre para uma série de problemas que, se antes germinavam na ficção machadiana, agora despontam com força total. Poderíamos mesmo pensar que, diante da polêmica envolvendo o seu nome e atraindo tantos intelectuais da época, Machado de Assis, por timidez, por tédio à controvérsia, ou por não acreditar na eficácia de tais querelas, recusa-se a participar delas, tentando descobrir uma outra maneira de provocar, fazer apelo, dar piparotes no seu leitor. E encontra, na ficção, um meio de responder mais eficaz, talvez mesmo a solução para a questão da crítica...

É o que passamos a analisar, tomando como exemplo um dos seus maiores romances. Observamos que Memórias Póstumas de Brás Cubas questiona a própria literatura, tal como era praticada até então, desde a sua dedicatória:

\author{
Ao verme \\ que \\ primeiro \\ roeu as frias carnes \\ do meu cadáver \\ dedico \\ como saudosa lembrança \\ estas \\ MEMÓRIAS PÓSTUMAS \\ (MACHADO DE ASSIS, 1971, v.I, p. 511)
}


Trata-se de um veemente apelo ao leitor, forçando-o a refletir sobre as técnicas da narrativa tradicional, linear, imitadora da escrita da História. Assim, quem escreve o romance é um defunto autor, para quem a campa foi outro berço (MACHADO DE ASSIS, 1971, v. I, p. 513), ou seja, a morte do personagem suscita a vida do autor, para grande perplexidade do leitor. $\mathrm{O}$ que significaria essa morte que engendra a vida? O que seria preciso morrer para fazer viver? Teria essa metáfora alguma coisa a ver com a questão da crítica no momento, que morria simplesmente porque caíra no vazio estéril da polêmica, da retórica, da pura importação de idéias, sem reflexão adequada? Seria preciso matar essa crítica, eliminá-la pela sua ineficácia (como morrera Brás Cubas), para que ela ressurgisse na ficção, questionando a própria literatura, bem como o sistema ideológico em que esta se desenvolvia?

Aceitando essas suposições, a explicação fornecida pelo defunto autor ao seu possível leitor pode nos fornecer mais algumas pistas para descobrirmos a resposta que Machado dava a seus contemporâneos:

Trata-se, na verdade, de uma obra difusa, na qual eu, Brás Cubas, se adotei a forma livre de um Sterne, ou de um Xavier de Maistre, não sei se lhe meti algumas rabugens de pessimismo. Pode ser. Obra de finado. Escrevi-a com a pena da galhofa e a tinta da melancolia, e não é difícil antever o que poderá sair desse conúbio (MACHADO DE ASSIS, 1971, v. I, p. 513).

São cada vez mais numerosos os estudos sobre as influências inglesas no humour machadiano, essa mistura de negro ceticismo com o riso, associação que o próprio autor define tão bem na metáfora da pena da galhofa e a tinta da melancolia. Isso nos leva a crer que esse conúbio continha a pista para explicar o seu comportamento durante toda a polêmica com o seu nome. Tédio à controvérsia, é lógico, sobretudo porque a controvérsia se dá a partir de temas inteiramente vazios. O que Machado nos deixa entrever nessa advertência é que é preciso manter o silêncio do desdém quando se trata de polêmicas literárias. Silêncio que significa ceticismo, descrença total na possibilidade de atuação com tais armas. Ceticismo que, por sua vez, engendra o riso irônico, produzindo o humour. Em que molde, a não ser o humorístico, havia Machado de Assis de vazar a virtude criadora que o impeliu para a Arte? (MAYA, 1912, p. 51), pergunta Alcides Maya no seu interessante trabalho. Na verdade, em uma nação que mal se organizava, com uma independência recém-proclamada pelo próprio colonizador, 
uma literatura por se afirmar e uma crítica que teimava em aplicar idéias importadas do Velho Mundo à nova realidade que se criava, um público leitor escassíssimo, qual seria a solução do intelectual? Participar cada vez mais de polêmicas, substituir a reflexão teórica por exercícios de retórica, em que o que contava era a oratória, o discurso bem construído?

Teriam, realmente, a timidez e o tédio à controvérsia impedido o nosso autor de entrar por esse caminho? Ou foi a certeza do vazio, da ineficácia dessas polêmicas que o levaram a praticamente abandonar a crítica literária, passando a fazer, desde então, literatura crítica? Nas próprias Memórias Póstumas temos um exemplo bem expressivo dessa retórica vazia que Machado recusa. Narrando o seu próprio enterro, o defunto autor relata o discurso que um amigo proferira à beira do seu túmulo:

Vós, que o conhecestes, meus senhores, vós podeis dizer comigo que a natureza parece estar chorando a perda irreparável de um dos mais belos caracteres que têm honrado a humanidade. Este ar sombrio, estas gotas do céu, aquelas nuvens escuras que cobrem o azul como um crepe funéreo, tudo isso é a dor crua e má que lhe rói à natureza as mais íntimas entranhas, tudo isso é um sublime louvor ao nosso ilustre finado (MACHADO DE ASSIS, 1971, v. I, p. 514).

Ouvindo este discurso, reflete o defunto autor: Bom e fiel amigo! Não, não me arrependo das vinte apólices que lhe deixei! Ironia, principalmente quando nos lembramos que o leitor machadiano pertence ao mesmo meio que o amigo de Brás Cubas, ou seja, é, muito provavelmente, capaz de fazer ou de aprovar esse tipo de discurso, pois está afeito a esse uso da retórica, tão arraigado no nosso país. Ou, com Luiz Costa Lima:

(...) em Machado a crítica da retórica assume desde logo a função de mostrar seu papel no Novo Mundo: o papel de encobrir o vazio, de dar-se ares de importância... a alusão irônica ao leitor assume seu verdadeiro peso ao notarmos que este pertencia ao mesmo meio dos usuários da retórica (1981, p. 64).

Isto fica ainda mais explícito no famoso conto publicado em 1882, em Papéis Avulsos, a Teoria do Medalhão, em que um pai aconselha ao filho, que completa vinte e um anos, a abraçar a carreira de medalhão, como garantia de sucesso na sociedade. Diz o personagem: Uma vez entrado na carreira, deves pôr todo o cuidado nas idéias que houveres de nutrir para 
uso alheio e próprio. O melhor será não as ter absolutamente (MACHADO DE ASSIS, 1971, v. II, p. 290). E, para alcançar esse resultado de ausência total de idéias, (...) há um meio, é lançar mão de um regímen debilitante, ler compêndios de retórica, ouvir certos discursos, etc. (MACHADO DE ASSIS, 1971, v. II, p. 290).

Assim, a retórica serve para preencher o vazio que a falta de reflexão provocara na sociedade. Leitor e assimilador das idéias européias, mas não conseguindo adaptá-las conveniente e adequadamente aos trópicos, ao intelectual só resta a disputa estéril, o discurso sem conteúdo, com que a crítica disfarçava o impasse em que caíra. E que era garantia total de sucesso na sociedade.

Ainda em Papéis avulsos, o mesmo livro em que publica a Teoria do Medalhão, encontramos o conto O Alienista, no qual o tratamento dessas questões é ainda mais sutil, e mais contundente. O conto nos fornece farto material para investigarmos a visão machadiana das idéias cientificistas e deterministas importadas. No início do texto ficamos sabendo que Simão Bacamarte, médico que havia estudado em Coimbra e Pádua, havia escolhido Dona Evarista para esposa porque ela

(...) reunia condições fisiológicas e anatômicas de primeira ordem, digeria com facilidade, dormia regularmente, tinha bom pulso, e excelente vista; estava assim apta para dar-lhe filhos robustos, sãos e inteligentes (MACHADO DE ASSIS, 1971, v. I, p. 254).

Enfim, as razões da sua escolha são ditadas pelas idéias que ele aprendera na Europa. Mas Dona Evarista continua estéril, o que provaria a ineficácia da ciência. Recusando a se conscientizar desta verdade, Simão continua a acreditar nos métodos científicos: ela não engravida porque não aceita a dieta imposta por ele, médico renomado. Bacamarte encarnaria, assim, a própria figura do cientista forjado pelo século XIX, que vai de teoria em teoria em busca da verdade, sem nunca encontrá-la. Assim, vai pouco a pouco internando toda a cidade de Itaguaí no manicômio, pois cada habitante lhe parece corresponder a uma das hipóteses que ele está pesquisando. E note-se que ele é inteiramente honesto, não aceita nem mesmo remuneração, o que o move é realmente a paixão pela ciência. Tão honesto que, no fim, acaba se conscientizando da sua própria loucura e vai ele mesmo para a Casa Verde. Estaria Machado metaforizando o suicídio da razão, perdida 
entre teorias que se contrapõem, vagando de experiência em experiência até chegar ao seu único termo possível: a loucura? Seria esta mais uma pista para o seu leitor, fazendo-o rir da busca infrutífera de Simão? Poderíamos considerar que Machado quer 'corroer' o sistema de pensamento vigente através da única arma de que dispõe: a escrita?

É interessante observar que, além da paródia do cientista, Machado ironiza também a aplicação da ciência à filosofia, apresentando um dos loucos como evolucionista:

Deus engendrou um ovo, o ovo engendrou a espada, a espada engendrou Davi, Davi engendrou a púrpura, a púrpura engendrou o duque, o duque engendrou o marquês, o marquês engendrou o conde, que sou eu (MACHADO DE ASSIS, 1971, v. II, p. 257).

Trata-se, evidentemente, da associação da ciência à ambição do poder, já que este louco se crê marquês e, o que é mais, descendente de Deus. Loucura da razão que se perde em meio a tantas teorias, sim, mas que busca sempre uma ordenação lógica. Como afirma Luiz Costa Lima, (...) é neste ambiente positivista e catalogador que a loucura é encarada como doença e privação (COSTA LIMA, 1991, p. 264). E que resultaria no enlouquecimento do próprio pesquisador das teorias sobre a loucura. Ora, se lembrarmos que por essa época estava se formando o pensamento freudiano na Europa, poderíamos ir muito mais longe nas nossas descobertas sobre a ficção machadiana. Faltando-nos fôlego, tempo e papel, basta-nos, por hora, pensar na loucura de um sistema intelectual que importa todas as suas teorias, sem reflexão própria, e que vai experimentando-as uma a uma, aplicando-as e descartando-as à medida que elas se verificam ineficazes.

Ainda temos, neste conto, o personagem Porfírio, que associa claramente as questões da retórica e da polêmica à ambição pelo poder. É pela retórica que o barbeiro triunfa de Simão Bacamarte e da Câmara. Mas, logo que assume o governo de Itaguaí, distribui uma proclamação ao povo e corre à procura do alienista:

A generosa revolução que ontem derrubou uma câmara vilipendiada e corrupta, pediu em altos brados o arrasamento da Casa Verde; mas pode entrar no ânimo do governo eliminar a loucura? Não. E se o governo não a pode eliminar, está ao menos apto para discriminá-la, reconhecê-la? Também não; é matéria 
de ciência. Logo, em assunto tão melindroso, o governo não pode, não deve, não quer dispensar o concurso de Vossa Senhoria. O que lhe pede é que de certa maneira demos alguma satisfação ao povo. Unamo-nos, e o povo saberá obedecer (MACHADO DE ASSIS, 1971, v. II, p. 277).

Além deste trecho do discurso de Porfírio ser um primor da arte da retórica, fornece-nos alguns dados importantes: em primeiro lugar, o que havíamos assinalado acerca da união estreita entre retórica e poder. É através da primeira que se chega ao segundo, como bem dizia o personagem da Teoria do Medalhão. Mas, chegado ao poder, para mantê-lo é necessário o apoio, ou o respaldo da ciência, o grande valor do século XIX. Assim, Porfírio propõe a união com Simão Bacamarte: Unamo-nos, e o povo saberá obedecer.

Percebemos aí uma crítica veemente de um sistema vazio de idéias, em que o que conta é a frase bonita, a retórica brilhante a esconder a nulidade do pensamento. E tudo isso sob a aparência de um embasamento científico, numa união entre retórica e ciência, em que a segunda serve de apoio à primeira. $\mathrm{Ou}$, nas palavras de Barreto Filho:

O Alienista pode se alimentar em certas fontes gerais do humorismo, mas é uma sátira muito precisa de defeitos nossos, especialmente de nossa imaturidade política, que nos tornava candidatos à tirania. É uma instalação em miniatura de uma ditadura científica, na vila de Itaguaí, pelo doutor Simão Bacamarte (BARRETO FILHO, 1980, p. 112).

Poderia Machado ter feito toda essa crítica das idéias da crítica nos seus textos de crítica literária? Se o fizesse, quem o teria lido? Ou, se o lessem, quem o teria aprovado? Teria nosso escritor descoberto que a ficção é uma maneira muito mais eficaz de se fazer crítica? No nosso entender, Machado de Assis, inicialmente, herdeiro da obsessão pedagógica do século XVIII, que faz da crítica literária um instrumento de formação do leitor, guiando-o e apontando-lhe caminhos, tenta contribuir, através dos seus textos teóricos, para a construção nacional. Cedo, porém, percebe que o que a intelectualidade da sua época está fazendo é mero jogo de retórica, sem reflexão de espécie alguma, importando-se idéias principalmente francesas, mas também inglesas, alemães, etc., como mero pretexto para polêmicas no vazio, que a nada levam. Descrente desses exercícios de retórica, não que- 
rendo compactuar com eles, nosso escritor praticamente abandona a crítica. Mas é justamente a partir desse abandono que a sua ficção vai se tornar mais crítica, 'corroendo' o sistema vigente em todos os sentidos, atacando em todas as frentes uma sociedade que ele percebe cruel e desumana. E, o que é mais impressionante, aplaudido pela mesma sociedade que critica, pelos mesmos homens que ele retrata de forma tão impiedosa. Como se explicaria isto? Teria o bruxo algum segredo para esta 'mágica'?

Podemos afirmar que é exatamente na escrita em palimpsesto que se encontra a chave do sucesso da sua obra. Na sua vertiginosa ascensão social, que o fez passar de moleque baleiro a presidente da Academia Brasileira de Letras, Machado de Assis foi obrigado a aprender todas as regras da boa sociedade, as boas maneiras que Rubião enlouquece por não conseguir assimilar. Revelando o funcionário público bem comportado, a escrita machadiana tem toda uma aparência de bom comportamento, de obediência às regras gramaticais, na linguagem castiça, na frase bem construída, na perfeição da forma, que tanto agradam aos seus críticos da época. Consegue, portanto, despistar o leitor pouco avisado e, então, dissimuladamente, como fazia Capitu para agradar a sociedade em que queria ser bem recebida, ele vai lançando o seu 'veneno', fornecendo pistas e falsas pistas que desorientam o seu leitor. E, na desorientação e descaminho, o 'piparote' que obriga à reflexão, corroendo o sistema através desse mesmo sistema, tentando conscientizar as mesmas pessoas de quem está rindo, ou com quem está sofrendo. Ou, nas palavras de Luiz Costa Lima,

(...) um texto aparente, 'segundo', capaz de interessar a seus leitores 'cultos' pelo sóbrio casticismo da linguagem, seus polidos torneios, suas personagens de pequenos vícios(...) Sob esses traços, eram deixadas as marcas de um texto 'primeiro', que a impressão tipográfica antes velava que apagava (COSTA LIMA, 1991, p. 253).

Machado descobre a única maneira possível de pensar criticamente a sociedade do seu tempo e, ao mesmo tempo, ser aplaudido por essa mesma sociedade. Sua crítica, muito mais vigorosa do que a dos seus pares, pois vai atacar inclusive as idéias que teriam gerado a própria crítica literária brasileira, tem possibilidades de atingir um público mais amplo do que os simples textos teóricos, lidos somente pela intelectualidade do momento. E, ironicamente, por causa da sua escrita em palimpsesto, ele vai 
justamente ser aplaudido e elogiado pelo mesmo sistema que está querendo questionar.

Parodoxo e drama do intelectual burguês, que pensa o mundo sem conseguir modificá-lo, que critica a sociedade e a sua classe social, embora continue pertencendo a ela, sua única salvação possível é a ficção, única saída para passar adiante uma visão lúcida do mundo. Poucos são os que o entendem, tanto na sua época como nos dias de hoje. Mas isto já estava previsto, como podemos perceber ainda nas primeiras páginas das Memórias Póstumas de Brás Cubas, mais precisamente, na advertência ao leitor, em que é dito:

Que Stendhal confessasse haver escrito um de seus livros para cem leitores, cousa é que admira e consterna. O que não admira, nem provavelmente consternará, é se este outro livro não tiver os cem leitores de Stendhal, nem cinqüenta, nem vinte, e quando muito, dez. Dez? Talvez cinco (MACHADO DE ASSIS, 1971, v. I, p. 513).

Consciente de que a sua ficção crítica não será entendida pelo leitor, Machado se contenta com os poucos que o puderem compreender. Assim fazendo, ele estaria lançando a semente para a liberdade da literatura brasileira com que sonhava, embora tenha que usar estratégias para lançá-la. E, como semente, ela seria em pequena quantidade, poucos leitores a compreendê-lo, mas que pudessem, a partir da sua obra, refletir criticamente sobre as questões que ele apresenta. Os outros, aqueles que o aplaudem sem compreendê-lo - e que são a grande maioria -, só fazem atestar a ineficácia de qualquer tentativa de atuação na sociedade por parte dos homens de letras. Machado se consola em lhes dar 'piparotes' sem ser entendido, rindo ironicamente de quem o aplaude sem entendê-lo. E reservando para os cinco leitores, os happy few a que se referia Stendhal, a responsabilidade de pensar nas questões abordadas pela sua obra, de maneira a tentar mudar alguma coisa na sociedade brasileira.

Muito provavelmente, ele não acreditava de fato nessa mudança, feita por tão pequena minoria intelectual, com tão reduzido poder de atuação. Talvez achasse que os 'cinco' não seriam capazes de fazer coisa alguma para mudar o que deveria ser mudado, no sistema intelectual vigente. Talvez essa descrença explicasse o tão decantado pessimismo em seus livros... Todos esses ‘talvez' são possíveis. Entretanto, o que temos de concreto é 
o fato de que um crítico, evidentemente intimidado pelo jogo de retórica vazia que é feito pelos seus colegas, abandona a crítica e passa a se dedicar quase que exclusivamente à ficção. E, a partir daí, sua escrita torna-se mais 'crítica' do que nunca, tematizando todos os grandes problemas do Brasil da sua época.

Machado, que volta a ser redescoberto atualmente, continua a ser enaltecido pelo que, no nosso entendimento, ele não é, principalmente: pelo estilo, pelos seus personagens, ou, na melhor das hipóteses, pela técnica narrativa. O crítico sofisticado da sociedade do seu tempo, das ideologias dominantes na sua época, da importação de idéias sem um pensamento local que as adapte adequadamente, continua restrito aos cinco leitores que ele espera encontrar para as Memórias Póstumas de Brás Cubas. Ou seja, aos poucos que percebem a sua escrita em palimpsesto pela qual, na sua obra da chamada segunda fase, há um texto segundo, aparentemente inofensivo, capaz de agradar ao público da época pelo casticismo da linguagem e pela intriga, mas que esconde, sob ele, um texto primeiro muito mais perigoso. Consciente de que no Brasil do século XIX há muito pouco espaço para um trabalho intelectual na crítica literária, Machado desiste de tentar atuar junto aos seus pares e, através da literatura, 'cutuca' o leitor, para que este reaja e colabore com ele, na sua escrita corrosiva.

Um dos primeiros a propor essa literatura crítica no Brasil, o escritor estabelece, assim, novas alternativas para as relações entre o pensamento e a ficção. A partir dele, a literatura brasileira se abre para a crítica no interior de si mesma, auto-reflexiva, característica da modernidade, o que nos leva a indagar do papel que passa a representar, então, a crítica literária e, por conseguinte, a questionar o seu papel na sociedade do século XIX e hoje...

\section{Referência Bibliográficas}

ASSIS, Joaquim Maria Machado de: Obra completa. Rio de Janeiro: Companhia José Aguilar Editora, 1971, 3 vols. . Crítica literária. Rio de Janeiro, W.M. Jackson, 1944.

BARRETO FILHO, José. Introdução a Machado de Assis. $2^{\text {a }}$ edição, Rio de Janeiro: Agir, 1980.

COSTA LIMA, Luiz. Dispersa Demanda. Rio de Janeiro: Francisco Alves Editora S.A., 1981. . Pensando nos trópicos, Rio de Janeiro: Rocco, 1991. 
MAYA, Alcides. Machado de Assis. Rio de Janeiro:J.Silva, 1912.

PUJOL, A. Machado de Assis. Rio de Janeiro: J. Olympio, 1934.

ROMERO, Sílvio. História da Literatura Brasileira. Rio de Janeiro: Garnier, 3 vols. 1902-3.

Introdução a Doutrina contra Doutrina. O evolucionismo e o positivismo no Brasil. in CANDIDO, Antonio (org.). Sílvio Romero, Teoria, Crítica e História Literária, São Paulo: EDUSP, 1978.

. Machado de Assis. Campinas: Editora da Unicamp, 1992.

VENTURA, Roberto. Estilo Tropical. São Paulo: Companhia das Letras, 1991. 